\title{
The Role of Hydroxyapatite Materials on Collagen Synthesis in Alveolar Bone Defects Healing
}

\author{
Yosefin Adventa ${ }^{1}$, Nanik Zubaidah ${ }^{2}$ \\ ${ }^{1}$ Undergraduate Student of Faculty of Dental Medicine, Airlangga University, Surabaya, Indonesia \\ ${ }^{2}$ Staff of Department of Conservative Dentistry, Faculty of Dental Medicine, Airlangga University, Surabaya, Indonesia
}

\begin{abstract}
Background: There are several cases in dentistry that cause alveolar bone defects, including periodontal disease, major trauma after tooth extraction, post-cyst enucleation, and post-surgery. Healing of alveolar bone defects can be treated in the form of bone grafting to restore the function and structure of damaged bone tissue. Hydroxyapatite has been proven to have some good properties such as biocompatible, bioactive, and osteoconductive. Osteoconductive materials serve as scaffold for osteoblasts to attach, grow, and differentiate to form new bone. Osteoblasts will synthesize collagen type 1 which functions to mineralize the bone matrix. Purpose: To explain the role of hydroxyapatite on collagen synthesis in alveolar bone defects healing. Reviews: In this review article discusses the healing process of alveolar bone defects, the characteristics of the hydroxyapatite material, collagen synthesis and also 4 kinds of natural substances that can be used as a source of hydroxyapatite material for supporting the bone healing process. These natural materials include bovine bones, egg shells, crab shells, and calcite rocks. Conclusion: Hydroxyapatite material has a role in collagen synthesis in the healing process of alveolar bone defects.
\end{abstract}

Keywords: Alveolar bone healing; Bone graft; Hydroxyapatite; Collagen

Correspondence: Nanik Zubaidah, Department of Conservative Dentistry, Faculty of Dental Medicine, Universitas Airlangga. J1. Mayjen. Prof. Dr. Moestopo No.47 Surabaya, 60132 Indonesia. Email: nanik-z@fkg.unair.ac.id

\section{INTRODUCTION}

Alveolar bone defects in dentistry can occur due to periodontal disease, major trauma after tooth extraction, post-cyst enucleation, and post-surgery. The healing process of alveolar bone defects is a complex and dynamic process consisting of four phases that are continuous, overlapping, and well programmed that involve tissue repair and regeneration. The process in every phase must occur precisely and regularly, including cells chemotaxis to the affected area, differentiation of mesenchymal cells, proliferation of bone-forming cells, synthesis of the extracellular matrix, osteoid mineralization, maturation, and bone remodeling. ${ }^{1-3}$.

Bone grafting is a way to restore the function and structure of bone tissue that has been damaged. Ideal bone grafts must be biocompatible and have osteogenic, osteoinductive, and osteoconductive capabilities. One of the biomaterials that is often used as a material for bone graft substitute is hydroxyapatite which has the chemical formula Ca10 (PO4) $6(\mathrm{OH})$. Hydroxyapatite has been proven to have good biocompatibility and osteoconductive properties so that it is well tolerated by the tissues of the human oral cavity and is able to stimulate osteoblast differentiation ${ }^{4,5}$. Osteoblasts will synthesize collagen and glycosaminoglycans (GAGs) which play a role in the bone mineralization process ${ }^{6}$.

Collagen is the main protein of connective tissue and is the most abundant protein in mammals, making up about $30 \%$ of the total protein content ${ }^{7,8}$. Currently there are 28 types of collagen that act as structural proteins that form and regulate the extracellular matrix (ECM), which is needed in wound healing, scar tissue, and the formation of bone matrix ${ }^{9,10}$. An important process in bone healing is the synthesis of various collagens, especially type I collagen, which makes up about $90 \%$ of the bone organic matrix and is required for adequate mineralization ${ }^{11}$. The purpose of this literature review is to explain the role of hydroxyapatite materials on collagen synthesis in alveolar bone defects healing.

\section{REVIEW(S)}

\section{Alveolar bone defects healing}

The process of bone defects repairing or healing consists of 4 phases, namely haemostasis phase, inflammatory phase, proliferation phase, and bone remodeling. ${ }^{12,13}$ 
The haemostasis phase in alveolar bone defects occurs due to the dynamic interaction of platelets and endothelial cells, coagulation and fibrinolysis also in balance situation which results in an increase of stable blood clots formation ${ }^{13}$. The second phase is the inflammatory phase. The manifestations that appear in the inflammatory phase are erythema (soft lumps), edema (swelling), pain and warmth, and usually lasting about three days. In the inflammatory phase there is an increase of vascularization and the migration of inflammatory cells such as lymphocytes, granulocytes and monocytes ${ }^{14}$.

At the molecular level, the proliferation phase is mediated by several growth factors such as TGF- $\beta$, BMP, FGF, IGF, and PDGF. In the proliferation phase of alveolar bone healing, bone formation occurs by intramembranous ossification, where bone develops without cartilage as an intermediary to form immature bone or woven bone. Growth factors will stimulate mesenchymal stem cells to differentiate into osteoblasts which produce an extracellular matrix which mainly consists of type I collagen and bone proteins such as osteocalcin. The extracellular bone matrix then undergoes calcification through the activity of osteoblasts which store calcium phosphate crystals in the extracellular matrix. When osteoblasts become "trapped" in the calcified extracellular matrix, osteoblasts will differentiate into osteocytes which serves as the constituent of a new bone ${ }^{13,15,16}$.

In the remodeling phase, woven bone that contain various types of collagen fibers and mineralized tissue will be resorbed by osteoclasts. Osteoblasts will turn into an active stage to produce osteoids so that the cavities made by osteoclasts can be filled again with bone matrix. The balance between osteoclast and osteoblast activity will make woven bone replaced with lamellar bone which has better mechanical stability and strength. ${ }^{13,16,17}$. On the other hand, collagen synthesis and degradation are also in balance condition. The deposition of new extracellular matrix still continuous, but occurs more slowly when compared with granulation tissue proliferation phase, whereas collagen degradation occurs due to excessive amounts of collagen in the defect area. Excessive amount of collagen can cause loss of normal anatomical structure, function, and tissue fibrosis. Collagen crosslinking takes place gradually which results in collagen fibers becoming more organized and tissue stability is also increased. The process of bone remodeling will result in restoration of the integrity, structure, and function of damaged bone tissue ${ }^{15,18,19}$.

\section{Hydroxyapatite materials}

bone defects can actually heal normally, but there are many conditions that make the healing process disturbed, such as inadequate vascularization, mechanical instability, infections, and systemic diseases ${ }^{20}$. The use of bone grafts is performed to fill or replace damaged bones as well as support the healing process to take place more optimally ${ }^{21}$. In dentistry, there are several bone graft materials that serves as a ridge preservation and augmentation of alveolar bone defect. Based on the constituent material, bone graft is classified into 1) autogenous, 2) allogenic, 3) xenogenic, and 4) synthetic or alloplastic. Autogenous bone graft is considered as the gold standard because it has osteogenic, osteoinductive, and osteoconductive abilities, but has several weakness such as limited availability of materials, causing bone resorption, and high morbidity ${ }^{22}$.

Biomaterials alternative that widely used as a bone graft material is hydroxyapatite. Raw materials for hydroxyapatite manufacture are easily available in large quantities and the costs required are relatively cheap ${ }^{23}$. Materials containing hydroxyapatite can come from natural materials such as mammalian bones and teeth, shells, coral and eggshells. Meanwhile, the artificial hydroxyapatite material can be processed through a series of chemical processes that carried out in the laboratory ${ }^{5}$. Hydroxyapatite bone graft has various sizes of porous matrix. The properties and end results after the application of hydroxyapatite material depend on the macro and micro porosity, such as volume fraction, pore size and pore connectivity. ${ }^{24,25}$

Hydroxyapatite has good biocompatibility properties, it can be accepted by human oral cavity tissue without causing toxicity. Hydroxyapatite also has the ability to bind to bone tissue chemically (bioactive), and is able to stimulate osteoblasts in the bone formation process (osteoconductive) ${ }^{5,26,27}$. Hydroxyapatite acts as a scaffold which is a biomaterial that is conductive to host cells and has functions to stimulate cell growth, differentiation and migration. ${ }^{28}$. The good characteristics of hydroxyapatite cause hydroxyapatite become widely used to treat various cases in dentistry, such as bone tissue reconstruction, dental implant coatings, soft tissue engineering and treatment of periodontal defects, filler restoration materials such as glass ionomer cement and composite resin ${ }^{5}$.

\section{Collagen synthesis and expression}

Mesenchymal stem cells and their derivates (fibroblasts, osteoblasts, odontoblasts, chondroblasts and cementoblasts) are the main producers of collagen. Several other cells that have a function to synthesize collagen are epithelial cells, endothelial cells, muscle and Schwann cells ${ }^{29}$. Type I collagen comes from procollagen type I which is produced by fibroblasts and osteoblasts. Type I procollagen contains $\mathrm{N}$-amino and $\mathrm{C}$-carboxy terminal propeptides which will be broken down by protease enzyme during the conversion of pro-collagen to collagen and then the bone matrix is formed ${ }^{30}$.

Type I collagen is the collagen that makes up more than $90 \%$ of the organic mass of bone and is the main collagen in the tendons, skin, ligaments, cornea, but very few in hyaline cartilage, brain and vitreous. Type I collagen is also synthesized in response to injury and occur in scar tissue. Collagen type I has a trimeric archetype with a Gly-X-Y triple helix structure that does not break and converge to form structural fibrils ${ }^{10,31}$.

In defects area, collagen type 1 first appeared on day 3 to day 5 then experienced a peak expression on day 7 to day 14 . Collagen type 1 continues to increase rapidly until day 21 and followed by the slower accumulation until day 
$90^{32}$. In the formation of bone tissue, osteoblasts synthesize and store collagen type I as the main constituent protein of the bone matrix. Collagen arranged in two types of arrangements, namely in the form of woven and lamellar. In woven bone, collagen fibers are arranged randomly while in lamellar bone collagen fibers are arranged longitudinally and transversely which called orthogonal pattern ${ }^{33}$.

\section{DISCUSSION}

Healing of alveolar bone defects is a complex and harmonious physiological process that relies on a wide variety of cells to restore the structure and function of damaged tissue. To maximize the healing process of alveolar bone defects, bone grafting was performed using hydroxyapatite materials. Hydroxyapatite is a mineral source of calcium and phosphate which is needed in bone reconstruction. Hydroxyapatite also has good osteoconductive properties so that it can act as a scaffold or a medium for osteoblasts to attach, grow and differentiate. In the healing process of bone defects, osteoblasts will secrete collagen type 1, which functions to mineralize the bone matrix to form new bone ${ }^{14,34}$.

One of the natural hydroxyapatite materials used as bone substitute is bovine bone. Bovine bone has a similar mineral structure and properties of human bones. The composition of bovine bone is $93 \%$ hydroxyapatite (Ca10 (PO4) $6(\mathrm{OH}) 2$ ) and 7\% $\beta$-tricalcium phosphate (Ca3 (PO4) 2 , B-TCP). The results of research conducted by Khotib et al. (2019) with the object of research is rat's femur defect is showing the value of the bone alkaline phosphatase. On day 14 showed a significant increase of BALP in soft callus formation because there had been a reaction between osteoblast formation and type 1 collagen. This faster bone formation occurred in the group given hydroxyapatite from the implant matrix Bovine Hydroxiapatite. BALP in the mineralization process served to prepare the alkaline atmosphere in the osteoid that was formed so that calcium could be easily deposited in the tissue. The deposition of calcium and phosphate minerals with ALP can cause bone formation, so that if the bone formation can be increased, the fracture healing can also be faster ${ }^{35}$.

A natural substance that can also be used as a source of hydroxyapatite is chicken egg shells. Egg shell consists of calcium carbonate $(94 \%)$, calcium phosphate $(1 \%)$, organic matter $(4 \%)$ and magnesium carbonate $(1 \%)$. In the research of Kattimani et al. (2019), chicken egg shell waste is processed into nanohydroxyapatite material which is applied into the socket after tooth extraction. The results of the study using micro-CT analysis concluded that preservation of the socket with nHA resulted a good bone regeneration. On micro-CT analysis, a new bone image is seen in the form of woven bone with thin trabeculae that contain lots of cellular osteoid and collagen fibers. Osteoids show eosinophilic areas with borders surrounded by osteoblasts and no osteoclasts or inflammatory cells were observed ${ }^{36,37}$.
Besides chicken egg shells, crab shells can also be used as a hydroxyapatite material. Crab shells contain $15.60-23.90 \%$ protein, $53.70-78.40 \%$ calcium carbonate, and $18.70-32.20 \%$ chitin, which also depends on the type of crab and where it lives. Dahlan et al. (2020) conducted a research that used hydroxyapatite gel from crab shells (Portunus pelagicus) which was applied to the socket after Wistar rats tooth extraction. The research was carried out by histopathological examination with Masson's Trichrome (MT) staining and observing collagen density on days 14 and 28. The results showed a significant increase of collagen fibers density in the group given hydroxyapatite gel from crab shells. Hydroxyapatite made from crab shells (Portunus pelagicus) contain high calcium carbonate $(\mathrm{CaCO} 3)$ of around $40-70 \%$. Calcium carbonate has properties that are easily absorbed by tissues, easily biodegradable, and osteoconductive so that it can support the process of forming new bone ${ }^{23}$.

Hydroxyapatite sources can also be synthesized from calcite rock. Calcite is rich in phosphor and can be obtained from clots of volcanic material, metamorphic rocks, and sediments such as limestone. Calcite has its constituent chemical elements, namely calcium $\left(\mathrm{Ca}^{2+}\right)$ and carbonate (CO3). Research conducted by Ardhiyanto et al. (2012), used hydroxyapatite synthesized calcite (PT. Omya, Surabaya, East Java) which is made through a hydrothermal process. Calcite hydroxyapatite bone graft was applied to the femur defect of Sprague Dawley rats and the osteoblast cells were observed using a microscope. In the group treated with hydroxyapatite calcite, the image of the soft callus has spread around the edges of the bone graft material, while in the negative control group the image of soft callus was just starting to fill the bone defect. The number of osteoblasts on day 28 increased in all groups compared to day 14 . Osteoblasts will synthesize collagen to help mineralize the bone matrix so that on day 56 the osteoblasts in soft callus begin to turn into osteocytes and form hard callus ${ }^{38}$.

The hydroxyapatite material used as bone graft is very dependent on the porosity of the material, because the higher the porosity on the surface of bone graft, the osteoconductivity of bone graft will also increase ${ }^{24,38}$.

\section{ACKNOWLEDGEMENT}

We gratefully thank to Department of Conservative Dentistry, Faculty of Dental Medicine, Airlangga University for giving support in the writing of this article.

\section{REFERENCES}

1. Rahmitasari F. Scaffold 3D Kitosan dan Kolagen Sebagai Graft pada Kasus Kerusakan Tulang. J Mater Kedokt Gigi. 2018;5(2):1.

2. Brasilino M da S, Stringhetta-Garcia CT, Pereira CS, Pereira AAF, Stringhetta K, Leopoldino AM, et al. Mate tea (Ilex paraguariensis) improves bone formation in the alveolar socket healing after tooth extraction in rats. Clin Oral 
Investig. 2018;22(3):1449-61.

3. Guo S, DiPietro LA. Critical review in oral biology \& medicine: Factors affecting wound healing. J Dent Res. 2010;89(3):219-29.

4. Bariyah N, Pascawinata A, Firdaus F. Gambaran Karakteristik Scaffold Hidroksiapatit Gigi Manusia Dengan Metode Planetary Ball Mill Menggunakan Uji Scanning Electron Microscope (Sem). B-Dent, J Kedokt Gigi Univ Baiturrahmah. 2016;3(2):131-8.

5. Mozartha M. Hidroksiapatit dan apilkasinya di bidang kedokteran gigi. Cakradonya Dent J. 2015;7(2):807-68.

6. Mahmudiati N. Kajian Biologi Molekuler Peran Estrogen / Fitoestrogen Pada Metabolisme Tulang Usia Menopause. In: Seminar Nasional VIII Pendidikan Biologi. 2011. p. 421-30.

7. Beckman MJ, Shields KJ, Diegelmann RF. Matthew J. Beckman Kelly J. Shields Robert F. Diegelmann. Biomed Eng (NY). 2004;1847-56.

8. Gadi DS, Trilaksani W, Tati N. HIstologi, Ekstraksi dan karakterisasi kolagen gelembung renang ikan cunang Muarenesox talabon. J Chem Inf Model. 2017;9(2):665-83.

9. Ismardianita E, Elianora D, Rosalina W, Nofrike L, Khairani VY. The effectiveness methanol extract clausena excavate on number of fibroblast and density of collagen fibers after tooth extraction. 2019;4(3):170-5.

10. Wallace JM, Chen Q, Fang M, Erickson B, Orr BG, Banaszak Holl MM. Type i collagen exists as a distribution of nanoscale morphologies in teeth, bones, and tendons. Langmuir. 2010;26(10):7349-54.

11. Lotz J, Hahn M, Prellwitz W, Gaertner T. Collagen type I metabolism after bone surgery. Arch Orthop Trauma Surg. 1999;119(3-4):212-6.

12. Velnar T, Bailey T, Smrkolj V. The wound healing process: An overview of the cellular and molecular mechanisms. J Int Med Res. 2009;37(5):1528-42.

13. Schlickewei CW, Kleinertz H, Thiesen DM, Mader K, Priemel M, Frosch K-H, et al. Current and Future Concepts for the Treatment of Impaired Fracture Healing. Int J Mol Sci. 2019;20(22):5805.

14. Guarnieri R, De Villiers P, Grande M, Stefanelli LV, Di Carlo S, Pompa G. Histologic evaluation of bone healing of adjacent alveolar sockets grafted with bovine and porcinederived bone: A comparative case report in humans. Regen Biomater. 2017;4(2):125-8.

15. Gomes P de S, Daugela P, Poskevicius L, Mariano L, Fernandes MH. Molecular and Cellular Aspects of Socket Healing in the Absence and Presence of Graft Materials and Autologous Platelet Concentrates: a Focused Review. J Oral Maxillofac Res. 2019;10(3):1-18.

16. Kini U, Nandeesh BN. Physiology of Bone Formation, Remodeling, and Metabolism. In: Radionuclide and Hybrid Bone Imaging. 2012. p. 29-57.

17. Oryan A, Monazzah S, Bigham-Sadegh A. Bone injury and fracture healing biology. Biomed Environ Sci. 2015;28(1):5771.

18. Beckman MJ, Shields KJ, Diegelmann RF. Collagen. In: Encyclopedia of Biomaterials and Biomedical Engineering. 2004. p. 324-34.

19. Häkkinen L, Larjava H, Koivisto L. Granulation Tissue Formation and Remodeling. Endod Top. 2012;24:94-129.

20. Taufik A, Zuhan A, Kusdaryono S. Chapter 3. Alveolar bone grafting: Rationale and clinical applications. In: Dental Implants and Bone Grafts Materials and Biological Issues. 2020. p. 43-87.

21. Mansour A, Al-Hamed FS, Torres J, Marino FT. Chapter 3
Alveolar bone grafting: Rationale and clinical applications. In: Dental Implants and Bone Grafts: Materials and Biological Issues Internet. Elsevier Ltd.; 2020. p. 43-87.

22. Khanijou M, Seriwatanachai D, Boonsiriseth K, Suphangul S, Pairuchvej V, Srisatjaluk RL, et al. Bone graft material derived from extracted tooth: A review literature. J Oral Maxillofac Surgery, Med Pathol Internet. 2017;31(1):1-7.

23. Dahlan A, Hidayati HE, Hardianti SP. Collagen fiber increase due to hydroxyapatite from crab shells ( Portunus pelagicus ) application in post tooth extraction in Wistar rats. 2020;14:3785-9.

24. Hing KA, Saeed S, Annaz B, Buckland T, Revell PA. Microporosity Affects Bioactivity of Macroporous Hydroxyapatite Bone Graft Substitutes. Key Eng Mater. 2004;254-256:273-6.

25. Prahasanti C, Subrata LH, Saskianti T, Suardita K, Ernawati DS. Combined hydroxyapatite scaffold and stem cell from human exfoliated deciduous teeth modulating alveolar bone regeneration via regulating receptor activator of nuclear factor- $\mathrm{Kb}$ and osteoprotegerin system. Iran $\mathrm{J}$ Med Sci. 2019;44(5):415-21.

26. Aarthi R, Ebenezer V, Sargunar B, Priyan S. Use of Nano Hydroxyapatite Bone Graft in. Biomed Pharmacol J. 2015;8:263-6.

27. Ardhiyanto HB. Peran hidroksiapatit sebagai bone graft dalam proses penyembuhan tulang. stomatognatik J Kedokt Gigi. 2015;118-21.

28. Sidiropoulos K, Roussou K, Intzes L, Economides N. Guided Tissue Regeneration in Surgical Endodontic Treatment: Case Report and Literature Review. Balk J Dent Med. 2019;23(2):102-7.

29. Seth P, Bhattacharya A, Agarwal S, Rm T, Thahriani A. Collagen : A review article. 2018;7(9):203-7.

30. PriyanaA. Peran pertanda tulang dalam serum pada tatalaksana osteoporosis. Universa Med Internet. 2016;26(3):152-9.

31. Gelse K, Pöschl E, Aigner T. Collagens - Structure, function, and biosynthesis. Adv Drug Deliv Rev. 2003;55(12):153146.

32. Larjava H. Oral Wound Healing: An Overview. In: Oral Wound Healing: Cell Biology and Clinical Management. 2013.

33. Shapiro F. Bone development and its relation to fracture repair. The role of mesenchymal osteoblasts and surface osteoblasts. Eur Cells Mater. 2008;15:53-76.

34. Ardhiyanto HB. Peran hidroksiapatit sebagai material bone graft dalam menstimulasi kepadatan kolagen tipe I pada proses penyembuhan tulang. Stomatognatic (J K G Unej). 2012;9(1):16-8.

35. Khotib J, Lasandara CS, Samirah S, Budiatin AS. Acceleration of Bone Fracture Healing through the Use of Natural Bovine Hydroxyapatite Implant on Bone Defect Animal Model. Folia Medica Indones. 2019;55(3):176.

36. Kattimani VS, Lingamaneni KP, Kreedapathi GE, Kattappagari KK. Socket preservation using eggshellderived nanohydroxyapatite with platelet-rich fibrin as a barrier membrane: A new technique. J Korean Assoc Oral Maxillofac Surg. 2019;45(6):332-42.

37. Kumar GS, Girija EK. Flower-like hydroxyapatite nanostructure obtained from eggshell: A candidate for biomedical applications. Ceram Int Internet. 2013;39(7):8293-9.

38. Ardhiyanto HB, Siswomihardjo W, Haniastuti T. Jumlah Osteoblas Pada Proses Penyembuhan Tulang Pasca Implantasi Hidroksiapatit Sintesis Dari Kalsit. dentika Dent J. 2012;17(2):145-9. 